\title{
THE ALTERNATIVE-ACTION REQUIREMENT: THE DERALMENT OF SANTA FE
}

\author{
E.C. LASHBROOKE, JR.*
}

In Santa Fe Industries, Inc. v. Green ${ }^{1}$ the United States Supreme Court instructed federal courts to refram from adjudicatimg imtracorporate disputes imvolving claims of unfairness or breach of fiduciary duty owed to the corporation or minority shareholders under the guise of section 10(b) of the Securities Exchange Act of $1934^{2}$ and rule $10 \mathrm{~b}-5^{3}$ in the absence of any manipulation, deception, misrepresentation, or nondisclosure. ${ }^{4}$ Five of the courts of appeals have disregarded that notice and have circumvented the Santa Fe decision by exploiting footnote fourteen ${ }^{5}$ of that opinion. These courts use an alternative-action requirement as part of the test for inateriality, although this requirement should not exist im the post-Santa Fe era.

Part IV of the Santa Fe opinion ${ }^{6}$ discusses the fourth element of the Cort v. $A s h^{7}$ test for implying a private civil cause of action for damages: whether "the cause of action [is] one traditionally relegated to state law." If the cause of action is one traditionally adjudicated by state courts, Cort and Santa Fe indicate that no private cause of action under federal securities laws should be iniplied. Footnote fourteen in Santa Fe apparently abrogates Part IV of the opinion, for it permits a federal cause of action im just such a case by making a cause of action under state law a prerequisite to a federal claim.

By appending the alternative-action requirement to the materiality standard, the courts of appeals have changed the question of material-

* Visiting Associate Professor of Law, Notre Dame Law School. B.A. 1967, M.A. 1968, J.D. 1972, L.L.M. 1977, University of Texas at Austin.

1. 430 U.S. 462 (1977).

2. 15 U.S.C. $\$ 78 \mathrm{j}$ (1976). For the relevant text of this section, see note 14 infra.

3. 17 C.F.R. $\$ 240.10$ b-5 (1981). For the relevant text of this regulation, see note 23 infra.

4. 430 U.S. at 476 .

5. Id. at 474 n.14. See note 24 infra for the full text of the footnote. For a discussion of the courts of appeals decisions, see notes 26-62 infra and acconupanying text.

6. 430 U.S. at 477-80. Only six Justices joined in Part IV of the opinion. Justice Brennan dissented, and Justices Steveus and Blackmun, concurring, refrained from joining Part IV.

7. 422 U.S. 66 (1975).

8. Id. at 78. 
ity from an objective one ${ }^{9}$ to a subjective one. Alternative-action, if a requirement, is more properly an element of reliance. ${ }^{10}$ This article examines the alternative-action rcquirement in light of the policy of Santa $\mathrm{Fe}$ and discusses the requirement's effect on the standards for materiality and reliance as elements of a cause of action for violation of section $10(\mathrm{~b})$ and rule $10 \mathrm{~b}-5$.

\section{FaIRNESs, BREACH OF FidUCiary DUty, AND Alternative ACTION}

Historically federal courts liave tended to give relief to slrareliolder plaintiffs in derivative suits when they perceivcd unfairness, despite the absence of fraud or bad faith. ${ }^{11}$ Plamtiffs used section 10(b) and more particularly rule $10 \mathrm{~b}-5$ as the primary vehicles to litigate fairness issues in federal court. ${ }^{12}$ In Santa Fe the Supreme Court supposedly put an end to this practice. ${ }^{13}$ In its examination of the statutory language of section 10(b), 14 the Court limited causes of action under section 10(b) and rule $10 \mathrm{~b}-5$ to practices that are "manipulative" in the technical

9. "The question of materiality, it is universally agreed, is an objective one, mvolving the significance of an omitted or misrepresented fact to a reasonable investor." TSC Indus., Inc. v. Northway, Inc., 426 U.S. 438, 445 (1976).

10. The reliance issue lias been defined as whether the particular plaintiff would have been influenced to act differently lad he known of the undisclosed information. List v. Fashion Park, Inc., 340 F.2d 457, 462 (2d Cir.), cert. denied, 382 U.S. 811 (1965).

11. See, e.g., Barrett v. Denver Tramway Corp., 53 F. Supp. 198 (D. Del. 1943), affd, 146 F.2d 701 (3d Cir. 1944). Barrett involved a reclassification of the stock of a solvent corporation, the effect of which was to divest the preferred shareholders' cumulative rights to a 12 year dividend arrearage. Although Judge Leahy held that the reclassification was not unfair under Delaware law, he wrote at length on the issue of fairness in the hope that the reviewing court might formulate an equitable standard for fairness. In another diversity case, Perlman v. Feldman, 219 F.2d 173 (2d Cir.), cert. denied, 349 U.S. 952 (1955), the Court of Appeals for the Second Circuit, in a confusing opinion, held that the sale of a controlling block of stock at a premiun was unfair to the minority slrareliolders even in the absence of fraud or bad faith. The court ordered the premium distributed on a pro rata basis anong all the shareholders.

12. Good discussions of this developinent of section 10(b) and rule 10b-5 appear in Jacobs, Role of Securities Exchange Act Rule 10b-5 in the Regulation of Corporate Management, 59 CoRNELL L. Rev. 27 (1973); Jennings, Federalization of Corporation Law: Part Way or All the Way, 31 Bus. LAw. 991 (1976); Roantree, Continuing Development of Rule 10b-5 as a Means of Enforcing the Fiduciary Duties of Directors and Controlling Shareholders, 34 U. PITT. L. REv. 201 (1972); Susinan, Use of Rule 10b-5 as a Remedy for Minority Shareholders of Close Corporations, 22 Bus. LAw. 1193 (1967).

13. See text accompanying notes 17-22 infra.

14. Section 10(b), 15 U.S.C. $\$ 78$ j (1976), states:

It shall be unlawful for any person, directly or indirectly, by the use of any mcans or instrumentality of interstate commerce or of the mails, or any facility of any national securities excliange-

(b) To use or employ, in counection with the purchase or sale of any security registered on a national securities exchange or any security not so registered, any manipulative or deceptive device or contrivance in contravention of suclr rules and regulations as the 
sense of artificially affecting market activity in order to mislead investors. ${ }^{15}$ "[I]nstances of corporate mismanagenent in which the essence of the complaint is that shareholders were treatcd unfairly by a fiduciary" are beyond the scope of section 10(b). ${ }^{16}$ Therefore, when there has been full disclosure of material facts, unfairness alone cannot sustain a cause of action under section 10(b) and rule 10b-5.

Santa $\mathrm{Fe}$ involved the use by a corporation of the Delaware shortform merger statute ${ }^{17}$ to freeze out the minority shareholders of a subsidiary, Kirby Lumber. ${ }^{18}$ Under the Delaware statute, a corporation owning ninety percent or more of the shares of another company can acquire that company without the vote of the minority shareholders simply by resolution of the board of directors. ${ }^{19}$ The statute requires only that the minority shareholders receive notice after the merger has been effected; their only remedy after notice is appraisal. ${ }^{20}$ In Santa $F e$, full disclosure had been made, and the crux of the shareholder's complaimt was the unfairness of the merger terms, particularly the cash value assigned to his Kirby stock. ${ }^{21}$ The Court declined to find a federal cause of action and relegated the shareholder to state law remedies. ${ }^{22}$

Thus, Santa Fe did not directly involve nondisclosure or misrepresentation under clause (b) of rule 10b-5.23 Unfortunately, the Court nonetheless chose to address the issue in a footnote. Footnote fourteen clearly implies that if the minority shareholders could have enjoined the merger under Delaware law, the corporation's failure to give advance notice of the merger would have constituted a "material nondisclosure" within the meaning of section $10(\mathrm{~b})$ and rule $10 \mathrm{~b}-5 .{ }^{24}$ The

\footnotetext{
Commission inay prescribe as necessary or appropriate in the public interest or for the protection of investors.

15. 430 U.S. at $476-77$.

16. $I d$.

17. Del. Code ANN. tit. 8 , § 253 (Michie 1974 \& Supp. 1980).

18. 430 U.S. at 465.

19. Del. CodE ANN. tit. 8, § 253 (Michie 1974 \& Supp. 1980); see 430 U.S. at 465.

20. Del. Code ANN. tit. 8, § 253 (Michie 1974 \& Supp. 1980).

21. 430 U.S. at $466-67$.

22. Id. at 478 .

23. Rule 10b-5, 17 C.F.R. $§ 240.10 b-5$ (1981), in relevant part states:

It shall be unlawful for any person . . .

(b) To make any untrue statement of a material fact or to omit to state a material fact necessary in order to make the statements made, in the light of the circumstances under whicl they were made, not misleading,

... in connection with the purchase or sale of any security.

24. The full text of footnote 14 is as follows:

In addition to their principal argument that the complaint alleges a fraud under clauses (a) and (c) of Rule 10b-5, respondents also argue that the complaint alleges nondisclosure and misrepresentation in violation of clause (b) of the Rule. Their major contention in this respect is that the majority shareloolder's failure to give the minority
} 
courts of appeals have seized on the language of footnote fourteen to address questions of fairness in cases in which the plaintiff has an alternative-state law action. ${ }^{25}$

The first of the alternative-action cases was SEC $v$. Parklane Hosiery Co. ${ }^{26}$ which involved nondisclosure in a premerger, going-private proxy. The Court of Appeals for the Second Circuit distinguished this case froin Santa $\mathrm{Fe}$ on three grounds. First, Parklane was a Securities Exchange Commission enforcement action for an injunction. ${ }^{27}$ Second, the shareholders of Parklane had an alternative: they could have sought and obtaimed injunctive relief in the state courts. ${ }^{28}$ Third, Parklane was a nondisclosure case whereas in Santa $\mathrm{Fe}$ there was full disclosure. ${ }^{29}$

The last of these distinctions is troublesome because Parklane involved nondisclosure of information that would have been relevant only in a state court proceeding for an injunction..$^{30}$ The information was not relevant to the consummation of the merger because, as in Santa $F e$, the minority shareholders could not have altered the outcome of the shareliolder vote. ${ }^{31}$ Moreover, Parklane is contrary to the court's own holding in Popkin v. Bishop, ${ }^{32}$ in which the court stated: "Underlying questions of the wisdom of [nergers] or even their fairness

advance notice of the merger was a material nondisclosure, even though the Delaware short-form merger statute does not require such notice. Brief for Respondents at 27. But respondents do not imdicate how they might have acted differently had they had prior notice of the merger. Indeed, they accept the conclusion of both courts below that under Delaware law they could not have enjoined the merger because an appraisal proceeding is their sole remedy in the Delaware courts for any alleged unfairness in the terms of the merger. Thus the failure to give advance notice was not a material nondisclosure within the meaning of the statute or the Rule. Cf. TSC Industries, Inc. v. Northway, Inc., 426 U.S. 438 (1976).

430 U.S. at 474 n. 14.

The Court was merely trying to dispose of respondent's contention that the complaint also alleged a rule $10 \mathrm{~b}-5(\mathrm{~b})$ violation in that failure to give minority shareholders advance notice of the merger was a material nondisclosure. Indeed, Delaware law does not require notice of a shortform merger. Del. Code ANN. tit. 8, \& 253 (Michie 1974 \& Supp. 1980).

25. After Singer v. Magnavox Co., 380 A.2d 969 (Del. 1977), and Tanzer v. International Gen. Indus., Inc., 379 A.2d 1121 (Del. 1977), in which the Delaware Supreme Court reestablished a cause of action based on fairness, the application of the alternative-action requirement would compel a different result than the decision in Santa Fe.

26. 558 F.2d 1083 (2d Cir. 1977).

27. Id. at 1088.

28. $I d$.

29. Id.

30. Id. The information in question was that the purpose for "going private" was to enable the president and primcipal shareholder of Parklane to discharge his personal debts from the Parklane treasury. Id. at 1085 . The suit for imjunction in state court could have been based on lack of a corporate purpose for the merger. Id. at 1088.

31. Id.

32. 464 F.2d 714 (2d Cir. 1972). In Popkin the plaintiff alleged that the exchange ratio in the proposed merger was unfair to the minority shareholders. He argned that this disparity would 
become tangential at best to federal regulation."33 In Popkin the court found that the minority shareholders were not powerless, for they could seek an injunction in state court even though they could not alter the outcome of the shareholder vote on the merger. ${ }^{34}$ Because of the existence of the alternative-state law action, the court relegated the plaintiffs to state court. Popkin was a precursor of the Santa Fe policy of relegating such cases to state court, which inakes the Second Circuit's holding in Parklane all the more puzzling.

The Second Circuit completed its circumvention of Santa $\mathrm{Fe}$ in Goldberg v. Meridor ${ }^{35}$ In Goldberg the parent corporation, when selling its assets to its subsidiary, failed to disclose certain financial information. This nondisclosure constituted a breach of its fiduciary duty to the subsidiary. Goldberg, a minority shareholder of the subsidiary, brought a derivative action to recover dainages. Under New York law $^{36}$ a shareholder of a purchasing corporation has no vote or other participation in such a transaction. The inajority was of the opinion, however, that New York law would have permitted Goldberg to seek injunctive rehef for breach of fiduciary duty. ${ }^{37}$ The majority, relying on Parklane, found that the availability of injunctive relief in state court made the misrepresented information material. ${ }^{38}$ The effect of this holding is that nondisclosure or misrepresentation of information that amounts to a breach of fiduciary duty is a violation of section $10(\mathrm{~b})$ and rule $10 \mathrm{~b}-5$ if an alternative-state law action is available. ${ }^{39}$ This result confounds another Second Circuit case ${ }^{40}$ decided one month prior to Goldberg, in whicll Judge Mansfield stated: "[I]t is clear since

have constituted a violation of section 10(b) and rule $10 \mathrm{~b}-5$ even if there had been full disclosure because the minority shareholders could not prevent the merger.

33. Id. at 720.

34. Id.

35. 567 F.2d 209 (2d Cir. 1977), cert. denied, 434 U.S. 1069 (1978).

36. N.Y. Bus. CoRp. LAW $\S 909$ (McKinney Supp. 1980).

37. 567 F.2d at 219. See N.Y. Bus. CoRp. LAw § 720 (McKinney 1963 \& Supp. 1980).

38. $567 \mathrm{~F} .2 \mathrm{~d}$ at $219-20$. "Indeed, we have quite recently recognized that the availability of an injunctive action under New York law constituted a sufficient basis for distinguishing the conclusion in the Green footnote with respect to materiality . . . " Id. at 220.

39. The alternative-action requirement is one of two bases for the opinion. The other basis is derived from Schoenbaum v. Firstbrook, 405 F.2d 215 (2d Cir. 1968), cert. denied, 395 U.S. 906 (1969). The majority used a modified test for inateriality combining Schoenbaum and TSC Indus., Inc. v. Northway, 426 U.S. 438 (1976). Because only the subsidiary's directors had to decide whether to purchase the parent's assets, the test for materiality was whether a substantial likelihood existed that if a reasonable director had known the facts lie would lave considered the information important in making his decision. The majority held that a reasonable director would have found the information important. $567 \mathrm{~F} .2 \mathrm{~d}$ at $217-19$. This rationale, although techirically complying with parts I through III of Santa Fe, conflicts with the policy underlying part IV of relegating these cases to state courts.

40. Browing Debenture Holders' Comin. v. DASA Corp., 560 F.2d 1078 (2d Cir. 1977). 
[Santa $\mathrm{Fe}$ ] that no [fiduciary] duties are imposed by federal law upon corporate directors and that a violation of any such state-law fiduciary duties, including non-disclosure of conflicts of interest or unfairness of a conversion price, will not support" a cause of action in federal court.41

In Wright v. Heizer Corp. ${ }^{42}$ the Court of Appeals for the Seventh Circuit also endorsed the alternative-action requirement. Heizer, which controlled the board of directors of International Digisonics Corporation (IDC), obtained a pledge of IDC's corporate assets as security for certain loans. ${ }^{43}$ Under Delaware law ${ }^{44}$ no shareholder action is required to pledge a corporation's assets. Wright, a minority shareholder, brought a derivative action based on section 10(b) and rule 10b5 for failure to disclose inaterial facts concerning the transaction. These facts were principally Heizer's degree of control over IDC and its self-dealing or breach of fiduciary duty in pledging IDC corporate assets to itself as controlling shareholder. As in Goldberg, the minority shareholder could have inaintained a state suit on behalf of the corporation to enjoin Heizer froin breaching its fiduciary duty to deal fairly with the corporation. 45 The court distinguished this case from Santa $\mathrm{Fe}$, explaining: "If [the minority] shareholders would have been powerless to prevent the proposed self-dealing by the controlling shareholder even if they possessed knowledge of all the facts the failure to disclose to thein would presumably be immaterial and reliance could not be shown." 46 In short, no cause of action existed under section 10 (b) and rule 10b-5 in the absence of an alternative-state law action. However, the existence of an alternative-state law action for an injunction transformed immaterial infornation into inaterial information and permitted a cause of action under section 10(b) and rule 10b-5.47

Other circuits soon followed the lead of the Courts of Appeals for the Second and Seventh Circuits, using Goldberg and Wright as authority for the alternative-action requireinent. The Court of Appeals for the Ninth Circuit adopted the requirement in Penfold $v$. Meikle, 48 which involved a decision of the board of directors of a not-for-profit

41. Id. at 1084 (footnote omitted) (emphasis added).

42. 560 F.2d 236 (7th Cir. 1977), cert. denied, 434 U.S. 1066 (1978).

43. The plaintiff had complained about four previous transactions. The first three transactions occurred prior to Heizer's acquisition of control of the IDC board. The complaint about the fourth transaction was the failure to disclose control in connection with a proposed amendment to the IDC articles of incorporation. 560 F.2d at 244-45.

44. Del. Code AnN. tit. 8, 8272 (Michie 1974 \& Supp. 1980).

45. 560 F. $2 \mathrm{~d}$ at $250-51$.

46. Id. at 250 .

47. Id.

48. 597 F.2d 1273 (9th Cir. 1979). 
corporation to sell the corporation's assets to a third party in exchange for securities. Under Idaho law a shareholder vote was not required, 49 but the board submitted the question to the shareholders for an advisory vote anyway. ${ }^{50}$ The plaintiff alleged that the defendants had violated section $10(\mathrm{~b})$ and rule $10 \mathrm{~b}-5$ in failing to disclose conflicts of interest of attorneys and directors and the personal hability of the directors for a corporate debt. Because the meinbers could have filed a derivative suit to enjoin the sale due to the alleged breaches of fiduciary duty, the court concluded that the meinbers were entitled to relief under section 10(b) and rule 10b-5.51 Citing Goldberg and Wright, the court held that "where shareholder approval is not required for a corporate act under state law, failure by directors and others to disclose conflicts of interest or unfairness to shareholders regarding the transaction constitutes a violation of rule 10b-5."52 The court stated that deception in violation of section 10 (b) and rule $10 \mathrm{~b}-5$ could exist precisely because of the existence of an alternative-state law action. ${ }^{53}$ The court's primary concern, consistent with Goldberg and Wright, was apparently that the transaction was grossly unfair to the meinbers.

The Court of Appeals for the Fifth Circuit followed suit in Alabama Farm Bureau Mutual Casualty Co. v. American Fidelity Life Insurance Co. ${ }^{54}$ a case involving a corporation's repurchase of its own stock. Dutifully citing the Santa $F e$ requirenent that a $10 \mathrm{~b}-5$ violation comprises deception or inanipulation in connection with a breach of fiduciary duty, ${ }^{55}$ the Fifth Circuit found "deception' in the defendants' failure to disclose that the repurchase plan was to be carried out in a inanner that would artificially inflate the price of AMFI's stock . . . and in their nrisrepresentation in the initial press release. . . ."56 As in Santa Fe, the minority shareholders were powerless to affect the repurchase plan which the board of directors had unanimously approved. The now-familiar difference was the existence of a state law reinedy: "We hold that all that is required to establish 10b-5 liability is a showing that state law remedies were available and that the facts shown inake out a prima facie case for relief [nnder state law]."57 The court

\footnotetext{
49. IDAHO CODE \& 30-145(2) (repealed 1979).

50. The membership did not approve the sale. 597 F.2d at 1282 .

51. Id. at 1292 .

52. Id. at 1291 .

53. $I d$. at 1292 .

54. 606 F.2d 602 (5th Cir. 1980), cert. denied, 101 S. Ct. 77 (1981).

55. See Santa Fe Indus., Inc. v. Green, 430 U.S. 462, $473-74$ (1977).

56. 606 F.2d at 613 .

57. Id. at 614. For a discussion of plaintiff's burden of proof requirements, see text accompanying notes 64-74 infra.
} 
determined that under Florida law the minority shareholder could have sought injunctive relief to halt the repurchase. ${ }^{58}$

Healey v. Catalyst Recovery, Inc. ${ }^{59}$ involved an acquisition of eighty percent of the stock of Catalyst Regeneration Services, Inc. (CRS) by SCR, Inc., the predecessor of Catalyst Recovery, and a subsequent merger of CRS with a SCR subsidiary. The accomplishment of the merger was guaranteed by the eighty percent block of CRS stock held by SCR. The plaintiff could not have prevented the merger. Nonetheless, the plaintiff alleged a violation of section $10(\mathrm{~b})$ and rule $10 \mathrm{~b}-5$ in that defendants failed to disclose information requested by the plaintiff. ${ }^{60}$ Although an action for an injunction was not available under Texas law absent fraud, an appraisal remedy was available. ${ }^{61}$ Over a strong dissent by Judge Aldisert, the Court of Appeals for the Third Circuit lield that "[w]here a misrepresentation or omission of material information deprived a proper plaintiff minority shareholder of an opportunity under state law to enjoin a inerger, there is a cause of action under rule 10b-5."62 The court therefore remanded the case to the district court to determine if the mjunction remedy was available to the plaintiffs under Texas law and their reasonable probability of success.

The Courts of Appeals for the Second, Third, Fifth, Seventh, and Nimth Circuits have circunivented the Supreme Court's holding in Santa $\mathrm{Fe}$ by deriving an alternative-action requirement froin footnote fourteen of that opinion. In the words of Judge Aldisert, dissenting in Healey after discussing Goldberg, Wright, Penfold, and Alabama Farm Bureau Mutual Casualty Co.: "We thus have a classic exanple of illicit precedential inbreeding in which a nuniber of decisions are cited to support a legal precept, although none of them provides a fair statement of reasons for the conclusion."63

\section{Burden AND Extent of Proof}

The language of footnote fourteen indicates that if an alternativeaction requirement exists, plaintiffs must affirmatively plead the alter-

58. 606 F.2d at 614 .

59. 616 F.2d 641 (3d Cir. 1980).

60. See id. at 644-45. Primarily, the plaintiff wanted information concerning the rationale for the exchange rate and the identity of persons who fixed the exchange rate for the merger. Id. at 644 n.2.

61. See Tex. Bus. Corp. Act ANN. \& 5.16.E (Vernon 1980).

62. 616 F.2d at 648 .

63. Id. at 656. 
native-action. ${ }^{64}$ The courts of appeals disagree on what constitutes sufficient pleading and proof. The issue is whether merely alleging the availability of an alternative-action is sufficient or whether a higher standard, such as proof that plaintiff would have succeeded in state court, is required.

Not all of the circuits have set a standard for pleading and proof. In Goldberg the complaints did not even mention an alternative-action; 65 the majority found sua sponte that a suit for injunction existed under New York law. ${ }^{66}$ Judge Meskill, dissenting, would have placed the burden of proof on the plaintiff to show a substantial likelihood that he would have brought a state suit had the breach of fiduciary duty been known. ${ }^{67}$ The Court of Appeals for the Fifth Circuit has required proof of the availability of a state law remedy and a reasonable basis for state rehef. ${ }^{68}$ The court stated that the plaimtiff did not have to prove that his state action would have been successful.69 The Court of Appeals for the Third Circuit remanded Healey for findings on the probability that the plaintiff would secure a state court injunction..$^{70}$ The plaintiff had to demonstrate that, assuming he had knowledge of the undisclosed information, there was a reasonable probability of success in obtaining an imjunction. ${ }^{71}$ Similarly, in Penfold the Court of Appeals for the Ninth Circuit placed the burden upon the plaintiff to show that he would have obtamed an injunction or damages in state court in excess of any appraisal remedy. ${ }^{72}$

Certainly plaintiffs should be required to do more than inerely allege that a state suit was available and that they would have sought that remedy had they known of the breach of fiduciary duty or unfairness. Otherwise, virtually all plaintiffs who are able to show that their states permit injunctive or other relief in such cases will have established a federal cause of action. If the Supreme Court truly intended to impose an alternative-action requirement on a cause of action under section $10(b)$ and rule 10b-5, plaintiffs should be required to show a high probability of success im state court given the policy underlying Santa

64. "But respondents do not indicate how they might have acted differently . ..." Santa Fe Indus., Inc. v. Green, 430 U.S. 462, 474 n.14 (1977) (emphasis added). See note 24 supra.

65. Goldberg v. Meridor, 567 F.2d at 224.

66. Id. at 219-20.

67. Id. at 222 (Meskill, J., dissenting).

68. Alabama Farm Bureau Mut. Cas. Co. v. American Fidelity Life Ins. Co., 606 F.2d 602, 614 (5th Cir. 1980), cert. denied, 101 S. Ct. 77 (1981).

69. Id.

70. 616 F.2d at $647-48$.

71. Id.

72. Penfold v. Meikle, 597 F.2d at 1294. 
$\mathrm{Fe}$ of clearing the federal docket of these cases. Moreover, in most of these alternative-action cases the plaintiff did resort to the state court initially or concurrently but abandoned the suit in favor of the federal action under section $10(\mathrm{~b})$ and rule $10 \mathrm{~b}-5 .^{73}$ Federal courts have long discouraged this kind of forum shopping. ${ }^{74}$ Failure to impose a high burden of proof is even inore onerous in ight of Santa Fe's underlying rationale that the very existence of state law remedies, such as appraisal rights and suits for breach of fiduciary duty, favor relegating these suits to state court and militate against implying a federal cause of action under section $10(\mathrm{~b})$ and rule $10 \mathrm{~b}-5$. The courts of appeals have turned this rationale on its head by holding that it is the existence of those state law remedies that give rise to the federal cause of action.

\section{Materiality, Reliance, AND Alternative Action}

Since the inception of an implied civil cause of action for a violation of section $10(\mathrm{~b})$ and rule $10 \mathrm{~b}-5,{ }^{75}$ the federal courts have been formulating a definition of inateriality. ${ }^{76}$ The test for materiality has ranged froin a realistic view ${ }^{77}$ to a reasonable inan standard ${ }^{78}$ to a marketplace effects test. ${ }^{79}$ The Supreine Court cases that define materiality involve section $14(\mathrm{~b})^{80}$ and rule $14 a-9^{81}$ rather than section $10(b)$ and

73. In Goldberg a parallel action on behalf of the corporation had been filed in a New York State Supreme Court. 567 F.2d at 225. In Alabama Farm Bureau Mutual Casualty Co. the plaintiff had filed state law claims in Escambia County Circuit Court in Florida. 606 F.2d at 607. In Healey the plaintiff filed an appraisal petition in Texas State Court which was dismissed without prejudice. 616 F.2d at 645 . In Penfold the plaintiffs voluntarily defaulted in a state court suit for an injunction and permitted a judgment to be entered dismissing the suit. 597 F.2d at 1283-84.

74. See Rosenfeld v. Black, 445 F.2d 1337, 1341 n.5 (2d Cir. 1971), cert. dismissed, 409 U.S. 802 (1972) (under SuP. CT. R. 60).

75. See Kardon v. National Gypsum Co., 69 F. Supp. 512 (E.D. Pa. 1946).

76. See, e.g., Smallwood v. Pearl Brewing Co., 489 F.2d 579 (5th Cir.), cert. denied, 419 U.S. 873 (1974); Kohler v. Kohler Co., 319 F.2d 634 (7th Cir. 1963); Kardon v. National Gypsum Co., 73 F. Supp. 798 (E.D. Pa. 1947).

77. Such a test is whether the fact is one "which would materially affect the judgment of the other party to the transaction." Kardon v. National Gypsum Co., 73 F. Supp. 798, 800 (E.D. Pa. 1947). The realistic view is the one preferred by Jennings and Marsh. See R. JENNinos \& H. Marsh, SeCurities Regulation 954 (4th ed. 1977).

78. "The basic test of materiality . . . is whether a reasonable inan would attach importance ... in determining his choice of action in the transaction in question." SEC v. Texas Gulf Sulphur Co., 401 F.2d 833, 849 (2d Cir. 1968) (emphasis in original), cert. denied, 394 U.S. 976 (1969) (quoting List v. Fashion Park, Inc., 340 F.2d 457, 462 (2d Cir.), cert. denied, 382 U.S. 811 (1965)).

79. In Kohler v. Kohler Co., 319 F.2d 634 (7th Cir. 1963), the Court of Appeals for the Seventh Circuit formulated a test that measures the effect of the nondisclosure on the value of the security in the market place. $I d$. at 642 . This test eliminates both the "reasonable" and the actual investor from the consideration of materiality.

80. 15 U.S.C. \& 78n(a) (1976).

81. 17 C.F.R. \& 240.14a-9 (1981). 
rule $10 \mathrm{~b}-5 .{ }^{82}$ Serious differences arose about whether the same standard should apply to section $10(\mathrm{~b})$ and rule $10 \mathrm{~b}-5 .{ }^{83}$ Moreover, it was uncertain whether a uniform standard should apply within rule 10b-5 itself. ${ }^{84}$ Simce the Supreme Court's decision in TSC Industries, Inc. $v$. Northway, Inc. ${ }^{85}$ however, and its subsequent use of that standard in Santa Fe ${ }^{86}$ the courts of appeals have adopted the TSC Industries standard for rule 10b-5.87 The standard that the Supreme Court provided in TSC Industries is an objective one: whether "there is a substantial likelihood that a reasonable shareholder would consider [the omitted fact] important in deciding how to vote." 88

The alternative-action requirement has modified this test for materiality. Material nondisclosures now imclude a corporation's failure to inform sharelıolders, in timely fashion, of inergers or other transactions

82. TSC Indus., Inc. v. Northway, Inc., 426 U.S. 438 (1976); Mills v. Electric Auto-Lite Co., 396 U.S. 375 (1970). Materiality was not an issue in Mills; nevertheless, Justice Harlan explained:

Where the misstatement or omission in a proxy statement has been shown to be "material," as it was found to be here, that determination itself indubitably embodies a conclusion that the defect was of such a character that it might have been considered important by a reasonable shareholder who was in the process of deciding how to vote. This requirement that the defect have a significant propensity to offset the voting process is found in the express terms of Rule 14a-9, and it adequately serves the purpose of ensuring that a cause of action cannot be established by proof of a defect so trivial, or so unrelated to the transaction for which approval is sought, that correction of the defect or imposition of hability would not further the imterests protected by $\S 14(\mathrm{a})$.

Id. at 384 (footnote omitted). Several courts seized on Justice Harlan's language as a definition of materiality. See, e.g., Gould v. American Hawaiian Steamship Co., 331 F. Supp. 981,986 (D. Del. 1971), affd, 535 F.2d 76I (3d Cir. 1976); Beatty v. Bright, 318 F. Supp. 169, I73 (S.D. Iowa 1970); Berman v. Thomson, 314 F. Supp. I031, I033 (N.D. Ill. 1970). But see Gerstle v. GainbleSkogmo, Inc., 478 F.2d 1281, 130I-02 (2d Cir. 1973).

83. In Woolf v. S.D. Cohn \& Co., 515 F.2d 591 (5th Cir. 1975), the Court of Appeals for the Fifth Circuit apphied a test for rule 10b-5 different from that for rule 14a-9, but the Supreine Court remanded the case for reconsideration in light of TSC Indus., Inc. v. Northway, Inc., 426 U.S. 944 (1976), and the court then adopted the TSC Industries standard. 546 F.2d 1252 (5th Cir.), cert. denied, 434 U.S. 831 (1977).

84. In Arber v. Essex Wire Corp., 490 F.2d 414, 418 (6th Cir.), cert. denied, 419 U.S. 830 (1974), a nondisclosure case, the court refused to adopt a different standard from that apphed in a false statement case and used the reasonable-man objective standard articulated by the Court of Appeals for the Second Circuit in SEC v. Texas Gulf Sulphur Co., 401 F.2d 833 (2d Cir. 1968), cert. denied, 394 U.S. 976 (1969). See note 78 supra. The court, however, articulated two different criteria for materiality in a nondisclosure case by requiring that the situation be "essentially extraordinary in nature and . . . reasonably certain to have a substantial effect on the market price" if disclosed. 401 F.2d at 848.

85. 426 U.S. 438 (I976).

86. Santa Fe Indus., Inc. v. Green, 430 U.S. at 474 n.14. See note 24 supra.

87. See Steadman v. SEC, 603 F.2d 1126, 1130 (5th Cir. 1979); Goldberg v. Meridor, 567 F.2d 209, 218-19 (2d Cir. 1977), cert. denied, 434 U.S. I069 (1978); Alton Box Board Co. v. Goldman, Sachs \& Co., 560 F.2d 916, 919-20 (8th Cir. I977); Wright v. Heizer Corp., 560 F.2d 236, 247-48 (7th Cir. I977), cert. denied, 434 U.S. 1066 (1978); Woolf v. S.D. Cohen \& Co., 546 F.2d 1252 (5th Cir.) (per curiam), cert. denied, 434 U.S. 83 I (1977).

88. 426 U.S. at 449 . See note 9 supra. 
that may be postponed or prevented by shareholder action in the state courts. Citing TSC Industries, the Santa Fe Court concluded in footnote fourteen that because plaintiff Green could not have enjoined the merger under Delaware law, failure to give him notice of the merger was not a material nondisclosure. ${ }^{89}$ The footnote implies that if Green had been able to enjoin the merger, the failure to give notice of the merger would have been a material nondisclosure and Green would have had a cause of action under section $10(\mathrm{~b})$ and rule $10 \mathrm{~b}-5$. The courts of appeals seized on this negative implication of footnote fourteen and modified the test for unateriality in situations in which an alternative-state law action may be available.

The scope of section 10(b) and rule 10b-5 took a quantum leap in $S E C$ v. Parklane Hosiery Co. ${ }^{90}$ when the Court of Appeals for the Second Circuit stated that information relevant to an attempt to enjoin a breach of fiduciary duty is material.91 Although not relevant to the merger decision, information relevant in a state suit to enjom a breach of fiduciary duty or unfairness became inaterial within the meaning of federal securities law.

Citing Parklane as precedent, the Second Circuit in Goldberg $v$. Meridor ${ }^{92}$ extended its new test for materiality to private civil causes of action. ${ }^{93}$ The availability of imjunctive relief under New York law distimguished Goldberg's situation from that of the plaintiff in Santa Fe. ${ }^{94}$ The Goldberg majority held that failure to disclose the parent corporation's breaches of fiduciary duty constituted material nondisclosure within the meaning of section $10(\mathrm{~b})$ and rule $10 \mathrm{~b}-5.9^{95}$ Although the dissent disputed the majority's finding of materiality, it did not controvert the majority's reading of footnote fourteen. The dissent beheved that an alternative-state law action was not available; 96 in effect, Goldberg was unanimous in its view that footnote fourteen expands the materiality test.

The Court of Appeals for the Seventh Circuit expanded the scope of section $10(\mathrm{~b})$ and rule 10b-5 even further when, in Wright v. Heizer Corp.,${ }^{97}$ it virtually equated unfairness with materiality. The Seventh

89. See note 24 supra.

90. 558 F.2d 1083 (2d Cir. 1977). See notes $26-29$ supra and accompanying text.

91. 558 F.2d at 1088.

92. 567 F.2d 209 (2d Cir. 1977), ccrt. denied, 434 U.S. 1069 (1978). See notes 35-41 supra and accompanying text.

93. $567 \mathrm{~F} .2 \mathrm{~d}$ at 220.

94. Id. at 220-21.

95. Id. at 221.

96. Id. at 223-24.

97. 560 F.2d 236 (7th Cir. 1977), cert. denied, 434 U.S. 1066 (1978). 
Circuit reasoned that if the individual defendant had disclosed his breaches of fiduciary duty, the minority shareholders could have brought a state court derivative suit for injunctive relief. Under the state's intrinsic-fairness standard, the defendant must prove that the transaction was fair to the corporation..$^{98}$ If the defendant satisfies this burden, the minority shareholders do not prevail in state court and, therefore, the nondisclosure is not material in federal court. On the other hand, if the defendant cannot ineet this burden, the minority shareholders prevail in state court and, therefore, the nondisclosure is material in federal court. ${ }^{99}$ Thus, the defendant's showing of fairness is determinative on the issue of materiality. 100

Wright indicates that the Seventh Cireuit has not abandoned its determination to force issues of fairness into antifraud actions. The result of this position is that materiality is measured on the basis of a state-court "effects" test determined by the fairness of the merger terms rather than by the objective reasonable-investor standard sanctioned by the Court. The state court standard of fairness is essentially a determination of fair value, with little or no regard to any nontangible attributes of stock ownership. ${ }^{101}$ Under the state court standard misrepresented or nondisclosed information not directly concerning the merger terms is not material if the terms are fair. As the Supreme Court recognized in Mills v. Electric Auto-Lite Co. ${ }^{102}$ a great number of violations would go unredressed in cases properly before the federal courts if this were the standard for materiality. ${ }^{103}$

In Penfold, the Court of Appeals for the Ninth Circuit used a modification of the TSC Industries objective standard ${ }^{104}$ as the standard for materiality, substituting the state-alternative action for the investment decision portion of the TSC Industries test. ${ }^{105}$ In Alabama Farm Bu-

98. E.g., Sinclair Oil Co. v. Levien, 280 A.2d 717, 720 (Del. 1971); Shlensky v. South Parkway Bldg. Corp., 19 Ill. 2d 268, 282-83, 166 N.E.2d 793, 800 (1960).

99. $560 \mathrm{~F} .2 \mathrm{~d}$ at 250.

100. Id. Mills v. Electric Auto-Lite Co., 403 F.2d 429 (7th Cir. 1968), vacated and remanded, 396 U.S. 375 (1970). In this proxy case the Seventh Circuit equated fairness with reliance. 403 F.2d at 436. The Supreme Court rejected this position on policy grounds. 396 U.S. at 381-83.

101. See David J. Greene \& Co. v. Schenley Indus., Inc., 281 A.2d 30 (Del. Ch. 1971); David J. Greene \& Co. v. Dunhill Int'l, Inc., 249 A.2d 427 (Del. Ch. 1968); Sterling v. Mayflower Hotel Corp., 33 Del. Ch. 20, 29, 89 A.2d 862, 869, affd, 33 Del. 293, 93 A.2d 107 (1952). But see Singer v. Magnovox Co., 380 A.2d 969 (Del. 1977), in which the Delaware Supreme Court required that a learing be held to determine the entire fairness of the transaction, including not only fair value but also intangibles. $I d$. at $977-78,980$.

102. 396 U.S. 375 (1970).

103. Id. at 381-85.

104. See text accompanying note 88 supra.

105. The test was whether a reasonable minority shareliolder "would lave considered this information in any decision whether or not to sue to block the sale." 597 F.2d at 1293. 
reau Mutual Casualty Co. the Court of Appeals for the Fifth Circuit adopted the same test with slightly different language. ${ }^{106}$ Similarly, in Healey the Court of Appeals for the Third Circuit adopted a standard based on the information's relevance to the decision to seek state law mjunctive relief. ${ }^{107}$ In addition, the Healey court required a showing of reasonable probability of success in state court to establish materiality. ${ }^{108}$

Part of the underlying problem is the difficulty of determining materiality using an objective standard. Some commentators believe that materiality can be determined only on a case-by-case basis, using a facts-and-circumstances test. ${ }^{109}$ Many courts become confused and speak of materiality in terms of the particular plaintiff; as a result, they fail to distimguish between materiality and reliance. Materiality is determined by an objective standard, but the reliance issue is whether the particular plaintiff would have been influenced to act differently had all material facts been disclosed. ${ }^{110}$ By appending the alternative-action requirement to the materiality standard, the courts have confused materiality and reliance.

The problem is compounded in nondisclosure or omission cases in which the establishment of materiality gives rise to a presumption of reliance. ${ }^{111}$ In such cases the question of reliance is necessarily liypothetical, mvolving a reasonable mvestor; but it is identical to the objective test for materiality. Therefore, im those cases the determination of materiality establishes reliance. This conclusion does not mean, however, that reliance is eliminated as a requirement in a nondisclosure or omission case. ${ }^{112}$ In both Mills and Affliated Ute Citizens v. United

106. "A reasonably prudent stockholder or disinterested director, in unaking an intelligent decision whether to take steps to stop the repurchase program, would certainly have considered it significant . ..." 606 F.2d at 614 .

107. "[T]he question is what information would be deeined to be material by the reasonable investor who conteinplates seeking an injunction against a inerger." 616 F.2d at 647.

108. Id.

109. R. Jennings \& H. Marsh, Securities Regulation 955 (4th ed. 1977).

110. List v. Fashion Park, Inc., 340 F.2d 457, 462 (2d Cir.), cert. denied, 382 U.S. 811 (1965). After drawing the distinction between materiality and rehance the List court confused thein by stating, "The proper test [of materiality] is whether the plaimtiff would have been influenced to act differently than he did act if the defendant had disclosed to him the undisclosed fact." 340 F.2d at 463.

111. See Affiliated Ute Citizens v. United States, 406 U.S. 128, 152-54 (1972).

112. In Titan Group, Inc. v. Faggen, 513 F.2d 234, 238 (2d Cir.), cert. denied, 423 U.S. 840 (1975), Judge Waterman rejected plaintiff's argument that rehance was no longer a necessary element of a cause of action under rule 10b-5. See also Gottheb v. Sandia Am. Corp., 452 F.2d 510, 516 (3d Cir. 1971), cert. denied, 404 U.S. 938 (1971); City Nat'l Bank v. Vanderbooin, 422 F.2d 221, 229 (8th Cir. 1970). 
States $^{113}$ the Supreme Court pondered the difficulty of proving reliance in a nondisclosure case; the Court's concern demonstrates the impossibility of eliminating reliance as a necessary element in such a case. ${ }^{114}$ If a showing of materiality establishes a presumption of reliance in a nondisclosure case, logic dictates that this presumption is rebuttable and that affirmative proof of nonreliance sliould be admitted. ${ }^{115}$

The courts of appeals's approach to the alternative-action requirement is misguided due to a wayward footnote. The Supreme Court articulated the proper materiality standard in TSC Industries and cited it as applicable to $10 \mathrm{~b}-5$ cases in Santa Fe. The objective standard for materiality unust be restricted to information relevant only to an investment decision and not to an alternative-action decision. Otherwise courts ignore the clear language of section $10(\mathrm{~b})$ and rule $10 \mathrm{~b}-5$, which prohibits certain practices only "in connection with the purchase or sale of any security." This language lias been interpreted by the Supreme Court to mean that a $10 \mathrm{~b}-5$ cause of action exists only for a particular type of litigant. ${ }^{116}$ The proper $10 \mathrm{~b}-5$ plaintiff is an investor who can prove that his trading judgment in a specific instance of a purchase or sale opportunity was affected due to the defendant's nondisclosure, misrepresentation, or manipulation. If the plaintiff had no investment decision to make, however, such as in a short-form merger, sale of assets, or other corporate decision not requiring shareholder participation, no cause of action exists under section 10(b) and rule 10b-5 as construed in Santa Fe. State law provides sufficient protection to such plaintiffs, mcluding appraisal remedies and injunctive relief or dainages for breach of fiduciary duty or unfairness. If the nondisclosure is material, and if it relates to an investment decision which the plaintiff must make, forbearance by the plaintiff to seek alternative-state court relief would establish reliance. The defendant would be free to estabhish affirmative proof of nonrehance based on the plaintiff's action or nonaction.

113. 406 U.S. 128 (1972).

114. Titan Group, Inc. v. Faggen, 513 F.2d 234, 238-39 (2d Cir.), cert. denied, 423 U.S. 840 (1975). See Affiliated Ute Citizens v. United States, 406 U.S. 128, 152-54 (1972); Mills v. Electric Auto-Lite, 396 U.S. 375, 384-85 (1970).

115. See Keirnan v. Homeland, Inc., 611 F.2d 785, $788-89$ (9th Cir. 1980); Arthur Young \& Co. v. United States Dist. Ct., 549 F.2d 686, 695 (9th Cir. 1977), cert. denied, 434 U.S. 829 (1977); Rochez Bros. v. Rhoades, 491 F.2d 402, 410 (3d Cir. 1974).

116. See Blue Chip Stamps v. Manor Drug Stores, 421 U.S. 723 (1975); Mitchell v. Texas Gulf Sulphur Co., 446 F.2d 90, 97 (10th Cir. 1971), cert. denied, 405 U.S. 918 (1972). See also Blackie v. Barrack, 524 F.2d 891, 908 (9th Cir. 1975), cert. denied, 429 U.S. 816 (1976). 


\section{CONCLUSION}

In Santa Fe Industries, Inc. v. Green, the Supreme Court deliberately closed the federal courthouse doors to litigants whose primary complaimt is a breach of fiduciary duty or unfairness in a corporate transaction. This policy decision was not made with callous disregard for the rights of these litigants because state law remedies are available to them. The courts of appeals have distorted the import of this policy. Through a misapplication of footnote fourteen of Santa $F e$, these courts recognize a cause of action under section 10(b) and rule 10b-5 im the very cases im which the Supreme Court would deny federal relief. Under the alternative-action requirement established by the courts of appeals a plaintiff must have an available state law remedy in order to establisl a 10b-5 action, but it is the existence of a state law remedy that justifies the Supreme Court's relegation policy. The Supreme Court and the courts of appeals have diametrically opposing views concerning the consequences of the availability of an alternative-state law remedy.

Although any Supreme Court pronouncement is worthy of study and cannot be summarily dismissed, it is incredible that the Supreme Court intended to impose by way of a footnote a new inateriality test for plaintiffs who lave an alternative-state court action. Yet that is how the courts of appeals have chosen to interpret Santa Fe. This imterpretation results in a dual standard of materiahity, dependent on the availability of an alternative-state action. Furthermore, abandonment of the objective for the realistic standard of nateriality confuses the eleinents of inateriality and rehance. Proof of forebearance from pursuit of the alternative-state law action is nore properly an element of reliance than of materiality under the objective standard. Forebearance in these circnmstances deinonstrates the plaintiffs' assumption that corporations have inade full disclosure of all material information and liave not breached their fiduciary duty. Failure to pursue a state law action does not prove materiality. Supreme Court review is imperative to check the spreading alternative-action requirement before the policy decision embodied in Santa $F e$ is further einasculated. 